\title{
THE MODIFIED LUNN-MCNEIL MODEL IN THE ASSESSMENT OF INTENSITY OF EXITING FROM THE UNEMPLOYMENT
}

\author{
Beata Bieszk-Stolorz \\ University of Szczecin, Faculty of Economics and Management, Szczecin, Poland \\ e-mail: beata.bieszk-stolorz@usz.edu.pl
}

ORCID: 0000-0001-8086-9037

(C) 2019 Beata Bieszk-Stolorz

This is an open access article distributed under the Creative Commons Attribution-NonCommercial-NoDerivs license (http://creativecommons.org/licenses/by-nc-nd/3.0/)

DOI: 10.15611 eada.2019.1.06

JEL Classification: C41, J64, E24

\begin{abstract}
The goal of the article is the assessment of the relative intensity of exiting from unemployment of long-term unemployed people with relation to their characteristics: gender, age, education, seniority and the number of subsequent registrations. The modified Lunn-McNeil model for various types of competing events: accepting the job, refusal and remaining causes of deregistration was used in the research. The modification consisted of the application of the stratified Cox model of non-proportional hazard, which allowed to assess the relative hazard after entering the state of long-term unemployment. The individual data of persons registered in the County [Powiat] Labour Office in Szczecin were used in the research. Age had the greatest impact on the change in relative hazard at the transition to long-term unemployment, while the level of education had no significant impact. The research made it possible to identify groups of people taking up work with the least intensity and refusing to take up jobs with the greatest intensity. These people should be taken into consideration during the process of creating the labour market policy
\end{abstract}

Keywords: Lunn-McNeil model, non-proportional hazard model, competing events, long-term unemployment.

\section{Introduction}

Long-term unemployment is one of the most dangerous phenomena on the labour market. It is, on the one hand, confirmation of the existence of persistent imbalance on the labour market, while on the other, it implies the negative effects in social and economic spheres. This is an important economic problem leading to negative consequences regarding both the unemployed and the whole economy. A long period of job-seeking is one of the main reasons for the depreciation of human capital. The effectiveness of counteracting unemployment depends on the proper identification of the groups of people threatened with long-term unemployment. On 
the basis of data from the Statistics Poland in 2017, these persons accounted for more than $40 \%$ of all registered unemployed persons in Poland (over $38 \%$ in the Zachodniopomorskie voivodeship, and over $30 \%$ in the Szczecin Powiat [county]). It is also the group generating high costs of professional activisation. Amongst the long-term unemployed persons there are those actively looking for employment, but their skills, professional experience and age mean that it is hard for them to find a job offer.

The goal of the article is an assessment of the relative intensity of exiting from unemployment by the long-term unemployed with respect to their attributes using a modified Lunn-McNeil model for various types of competing events: accepting a job, refusal, and other causes of de-registration. The applied models also allowed the assessment of changes in the intensity of transition to long-term unemployment depending on gender, age, education, length of service and the number of subsequent registrations. The hypothesis of the research was that the attributes of the unemployed differentiated the intensity of de-registration from the labour office. The article presents the research method, data used in the research, results of analysis and conclusions.

\section{Methodology of research}

The methods of survival analysis were applied in the research. They originate from demography and technical sciences. In the past, they were used to study human life expectancy and the reliability of devices. Nowadays it is also applied to study the duration of economic phenomena. The studied phenomenon may result in the occurrence of a specific event (death, onset of disease, failure, liquidation of a company, exiting from unemployment). The event may not occur before the end of the observation. Such an observation is considered as censored.

The basic term of survival analysis is the survival function denoting the probability that the event will not occur until at least to moment $t$. This is defined as follows:

$$
S(t)=P(T>t)=1-F(t)
$$

where: $T$ - duration of the phenomenon, $F(t)$ - cumulative probability density function of random variable $T$.

The second function used in the survival analysis is hazard function $(h)$. It describes the instantaneous potential of the occurrence of the event in moment $t$ under the condition of survival until moment $t$ and is defined as follows [Kleinbaum, Klein 2012]:

$$
h(t)=\lim _{\Delta t \rightarrow 0} \frac{P(t \leq T<t+\Delta t \mid T \geq t)}{\Delta t}
$$

where: $T$-duration of the phenomenon. 
In addition to the observations not completed before the end of the observation period, also those in which the audited unit disappears from the field of vision are right-censored. Moreover, if there is an end-of-observation event which excludes the occurrence of a relevant event [Pepe 1991], or a competing event, we also have a right-censored observation. In the analysis of causes of death, this may occur because of a specific disease (for example cancer) or it can be caused by the effects of treatment (complications after chemotherapy). Their differentiation is very important for the whole process of treatment. In the analysis of the reliability of devices, the competing risk is connected with the influence of the components on the whole system. The failure of the whole system may be the result of the failure of any of the components. In the case of various competing events ending the process, models of competing risks may be applied [Klein, Moeschberger 1984; Klein, Moeschberger 2003; Klein, Bajorunaite 2004]. Competing events are those whose occurrence excludes the occurrence of another event or fundamentally changes the probability of the occurrence of another event [Gooley et al. 1999]. If the occurrence of a certain type of event does not influence the probability of any other events [Crowder 1994, 1996, 1997], then it is assumed that the assumption about their independence is satisfied. Such a type of risk is considered as unconditional competing risk. It happens that the probability of transition between states depends on explanatory variables or on time and type of staying in the previous state. In such cases the analysed occurrence can be described by means of the competing risk models [Landmesser 2008].

Let $g=1,2, \ldots, K$ denote layers being the types of risk matching the $K$ competing risks. An alternative version of the Lunn-McNeil model can be used for the assessment of intensity of exiting from unemployment. This is the stratified Cox model with interactions in the form of [Kleinbaum, Klein 2012, pp. 425-495]:

$$
h_{g}^{* *}(t, X)=h_{0 g}^{* *}(t) \exp \left(\sum_{k=1}^{K} \sum_{j=1}^{p} \alpha_{k j} D_{k} X_{j}\right)
$$

where: $h_{0 g}^{* *}$ - basic hazard, $X_{1}, X_{2}, \ldots, X_{p}$ - explanatory variables, $D_{1}, D_{2}, \ldots, D_{K}-K$ dummy variables, $\alpha_{k j}$ - model parameters.

For specific $g=k \geq 1, D_{k}=1$ and $D_{k}{ }^{\prime}=0$ when $k^{\prime} \neq k$ occurs, by means of the expression $H R=\exp \left(\alpha_{k j}\right)$, hazard ratios (relative intensity) of the occurrence of the event of type $k$ are calculated [Bieszk-Stolorz 2018].

In order to analyse the changes of intensities of de-registration after transition into the state of long-term unemployment, the Cox non-proportional hazard model was used [Bieszk-Stolorz 2013]:

$$
h(t, X)=h_{0}(t) \exp (\beta X+\delta X \times f(t))
$$

where: $h_{0}$ - basic hazard, $X$ - explanatory variable, $f(x)$ - function depicting relationship between the hazard and time, $\beta, \delta$-model parameters. 
If parameter $\delta$ is significant (hypothesis $H_{0}: \delta=0$ is rejected), the influence of variable $X$ on the hazard is time-varying. In the conducted research, functions $f_{1}$ and $f_{2}$ are defined as follows:

$$
f_{1}=\left\{\begin{array}{l}
0 \text { for } t<t_{0} \\
1 \text { for } t \geq t_{0}
\end{array} \text { and } f_{2}=\left\{\begin{array}{l}
1 \text { for } t<t_{0} \\
0 \text { for } t \geq t_{0}
\end{array} .\right.\right.
$$

Such functions are called Heaviside's functions. By means of the $f_{1}$ function, the hazard ratio for events occurring before moment $t_{0}$ is obtained directly. The hazard ratio for a duration not shorter than $t_{0}$ can be obtained by using the $\delta$ parameter. However, in a such case it is impossible to obtain the standard error nor the $p$-value. Therefore the $f_{2}$ function was also used for the estimation of model parameters, which allowed to directly obtain the hazard ratio for events occurring in time not shorter than $t_{0}$.

After joining formulas (3) and (4), we obtained the formula allowing for the assessment of changes in the relative intensity of de-registration from the office due to various reasons after transition into long-term unemployment, in respect to the attributes of the unemployed persons. The modified Lunn-McNeil model takes the following form:

$$
h_{g}(t, X)=h_{0 g}(t) \exp \left(\sum_{k=1}^{K} \sum_{j=1}^{p} \alpha_{k j} D_{k} X_{j}+\sum_{k=1}^{K} \sum_{j=1}^{p} \delta_{k j} D_{k} X_{j} \times f(t)\right)
$$

where: $h_{0 g}$ - basic hazard, $f(t)$ - function depicting the relationship between the hazard and time, $X_{1}, X_{2}, \ldots, X_{p}$ - explanatory variables, $D_{1}, D_{2}, \ldots, D_{K}-K$ dummy variables, $\alpha_{k j}, \delta_{k j}$ - model parameters.

The influence of the unemployed persons' attributes on the intensity of de-registration from the labour office before and after the transition into the state of long-term unemployment was analysed. The duration of unemployment since the moment of registration in 2013 until the moment of de-registration due to a certain reason until the end of 2014 was analysed. Some of the observations were considered as right-censored. The following attributes were considered in the research: gender, age, education, seniority and the number of subsequent registrations in the office. Value $\exp \left(\delta_{k j}\right)$ allowed to determine the size of change (increase or decrease) of the relative hazard in the moment of transition into the state of long-term unemployment. The model used the dummy variables depicting the attributes of the unemployed persons. Dichotomous variables were coded zeroone and the multipartite variables were coded quasi-experimentally -1-0-1 [Brzeziński 2004; Walesiak 1996]. In the first case the hazard for the group coded as 1 was compared with the hazard estimated for the group 0 (reference groups: males, persons with seniority below 1 year, persons registered for the first time). In 
the second way of coding the hazards for each category was compared with the mean hazard for all categories of each attribute. The 1-0-1 coding consists in the fact that persons from one selected category are coded with the value " -1 ", persons described by the dummy variable are coded with "1" and those from the remaining categories , " 0 ". The reference group is in this case the "dummy" group, which can be described as mean for all groups ${ }^{1}$.

\section{Data used in the research}

The study used anonymous individual data on 22,078 unemployed persons obtained from the County Labour Office in Szczecin. The duration of unemployment of each unit since the registration moment in 2013 until the moment of de-registration due to certain reason at the end of 2014 was analysed. Some observations did not end with an event, or de-registration in the analysed period. Such observations are considered as right-censored. The influence of the attributes of the unemployed on the intensity of de-registration from the labour office before and after transition in to the state of long-term unemployment was analysed. The following attributes and their categories were considered: gender (men, women), age groups (18-24, 25-34, 35-44, 45-54, 55$59,60-64$ ), education (at most lower secondary, basic vocational, secondary general, secondary vocational, higher), seniority (less than 1 year, 1 year or more) and the number of subsequent registrations in the labour office (first registration, subsequent registration).

The data used in the research contain dozens of causes of de-registration. They are connected, among the other things, with taking a job, transition to pension, retirement, continuation of education, going abroad or refusal of employment. These causes were grouped. The three groups of competing events were considered: job, refusal and other causes. Taking a job consists of three subgroups: taking a job or other employment, taking a job subsidised by the labour office, business activity. Refusal is a group of causes in which the registered person was removed from the register through his/her own fault. The remaining causes of deregistration (other causes) are less numerous and, as earlier research shows, each of them had a marginal impact on the probability of de-registration from the labour office and therefore they were considered together. They are, inter alia, going abroad, change of residence beyond the area of the activity of the county labour office, death, appointment for essential military service, entering a stationary education, acquisition of rights to retirement, pension or allowance. The size of each group is presented in Table 1 .

${ }^{1}$ Further discussion on methods of coding of variables and interpretation of parameters can be found in [Bieszk-Stolorz 2013]. 
Table 1. Size of groups of causes of de-registration

\begin{tabular}{|c|c|c|c|c|c|c|}
\hline \multirow[b]{2}{*}{ Category } & \multicolumn{3}{|c|}{ Cause of de-registration } & \multirow{2}{*}{$\begin{array}{c}\text { Censored } \\
\text { observations }\end{array}$} & \multirow[b]{2}{*}{ Total } & \multirow{2}{*}{$\begin{array}{c}\text { Including } \\
\text { long-term } \\
\text { unemployed }\end{array}$} \\
\hline & Job & Refusal & Other & & & \\
\hline \multicolumn{7}{|c|}{ Gender ( coding $0-1)$} \\
\hline Male $P_{0}$ & 4,824 & 5,701 & 840 & 943 & 12,308 & 1,922 \\
\hline Female $P_{1}$ & 4,809 & 3,264 & 784 & 913 & 9,770 & 1,851 \\
\hline \multicolumn{7}{|c|}{ Seniority (coding 0-1) } \\
\hline Less than 1 year $D_{0}$ & 2,316 & 4,195 & 472 & 574 & 7,557 & 1,178 \\
\hline 1 year or more $D_{1}$ & 7,317 & 4,770 & 1,152 & 1,282 & 14,521 & 2,595 \\
\hline \multicolumn{7}{|c|}{ Number of registrations (coding $0-1$ ) } \\
\hline First registration $Z_{0}$ & 2,489 & 2,045 & 514 & 370 & 5,418 & 850 \\
\hline Subsequent registration $Z_{1}$ & 7,144 & 6,920 & 1,110 & 1,486 & 16,660 & 2,923 \\
\hline \multicolumn{7}{|c|}{ Education (coding -1-0-1) } \\
\hline At most lower secondary $S_{1}$ & 1,388 & 2,932 & 316 & 487 & 5,123 & 994 \\
\hline Basic vocational $S_{2}$ & 1,955 & 2,220 & 362 & 479 & 5,016 & 940 \\
\hline Secondary general $S_{3}$ & 1,219 & 1,223 & 207 & 210 & 2,859 & 435 \\
\hline Secondary vocational $S_{4}$ & 1,940 & 1,415 & 381 & 350 & 4,086 & 712 \\
\hline Higher $S_{5}$ & 3,131 & 1,175 & 358 & 330 & 4,994 & 692 \\
\hline \multicolumn{7}{|c|}{ Age (coding $-1-0-1)$} \\
\hline $18-24 W_{1}$ & 1,306 & 2,115 & 206 & 110 & 3,737 & 298 \\
\hline $25-34 W_{2}$ & 3,707 & 2,991 & 339 & 434 & 7,471 & 986 \\
\hline $35-44 W_{3}$ & 1,892 & 1,786 & 218 & 462 & 4,358 & 855 \\
\hline $45-54 W_{4}$ & 1,590 & 1,205 & 220 & 352 & 3,367 & 725 \\
\hline $55-59 W_{5}$ & 892 & 648 & 373 & 286 & 2,199 & 554 \\
\hline $60-64 W_{6}$ & 246 & 220 & 268 & 212 & 946 & 355 \\
\hline Total & 9,633 & 8,965 & 1,624 & 1,856 & 22,078 & 3,773 \\
\hline
\end{tabular}

Source: own elaboration.

In the analysed period almost $44 \%$ of persons took a job, $41 \%$ were removed from the register because of refusal, and just over $7 \%$ deregistered due to other causes. Censored observations (observations that did not end with the event until the end of 2014) consisted of over $8 \%$. The intensity of exiting unemployment was analysed with respect to the unemployment persons' attributes; $17 \%$ of all persons were long-term unemployed, $51 \%$ were male, $69 \%$ were persons that had worked for 1 year or longer, $77 \%$ were registered subsequently, $26 \%$ had at most lower secondary education and $26 \%$ were in the age group $24-34$ years.

\section{Research results}

The parameters of model (4) for both functions $f_{1}$ and $f_{2}$ were estimated. Because the transition into the state of long-term unemployment was analysed, it was assumed that $t_{0}=12$ months. If $f=f_{1}$ then $\exp \left(\alpha_{k j}\right)$ is the relative hazard of exiting unemployment due to the $k$-th cause for the $j$-th attribute before the twelfth month since the moment of registration. For $f=f_{2}$ the expression $\exp \left(\alpha_{k j}\right)$ is the relative 
hazard of exiting unemployment due to the $k$-th cause for the $j$-th attribute in the twelfth or subsequent month. In the case of variables: education and age group (coding -1-0-1), the decision about the construction of two types of models was made. The first type consisted of variables with indexes $2,3, \ldots, n$, while the second one of the variables with indexes $1,2, \ldots, n-1$. This allowed to determine the parameters, and thus the hazard ration for all the analysed categories. In the case of the dichotomous variables: gender, seniority and the number of subsequent registrations (coding 0-1) this was not done because one of both states of variables was assumed as the reference. Tables 2 to 4 present the results of the estimation of the models' parameters.

Table 2. The results of estimation of the modified Lunn-McNeil model for the following explanatory variables: gender $(P)$, seniority $(D)$ and the number of subsequent registrations $(Z)$

\begin{tabular}{|c|c|c|c|c|c|c|c|c|c|c|}
\hline 营 & 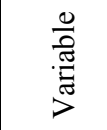 & 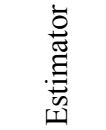 & 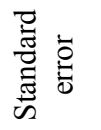 & 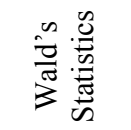 & 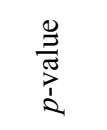 & $\begin{array}{l}\frac{0}{0} \\
\frac{\pi}{\pi} \\
\frac{\pi}{\nu}\end{array}$ & 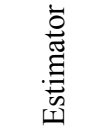 & 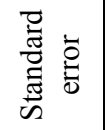 & 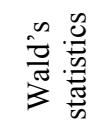 & 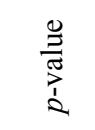 \\
\hline & \multicolumn{5}{|c|}{ Model for the $f_{1}$ function } & \multicolumn{5}{|c|}{ Model for the $f_{2}$ function } \\
\hline \multicolumn{6}{|c|}{$\chi^{2}=463.9019, p=0.0000$} & \multicolumn{5}{|c|}{$\chi^{2}=463.9019, p=0.0000$} \\
\hline \multirow{2}{*}{$\stackrel{0}{\circ}$} & $P$ & 0.1209 & 0.0213 & 32.1272 & 0.0000 & $P$ & 0.1931 & 0.0699 & 7.6274 & 0.0058 \\
\hline & $P \times f_{1}(t)$ & 0.0723 & 0.0731 & 0.9771 & 0.3229 & $P \times f_{2}(t)$ & -0.0723 & 0.0731 & 0.9771 & 0.3229 \\
\hline \multirow{2}{*}{ 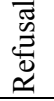 } & $P$ & -0.4636 & 0.0233 & 394.5448 & 0.0000 & $P$ & -0.2398 & 0.0656 & 13.3597 & 0.0003 \\
\hline & $P \times f_{1}(t)$ & 0.2237 & 0.0696 & 10.3172 & 0.0013 & $P \times f_{2}(t)$ & -0.2237 & 0.0696 & 10.3172 & 0.0013 \\
\hline \multirow{2}{*}{$\underset{\bar{D}}{\dot{\Xi}}$} & $P$ & .0244 & 0.0521 & 0.2195 & 0.6394 & $P$ & .1845 & 0.1649 & 1.2513 & 0.2633 \\
\hline & $P \times f_{1}(t)$ & 0.1601 & 0.1730 & 0.8563 & 0.3 & $P \times f_{2}(t)$ & -0.1601 & 0.1730 & 0.8563 & 0.3548 \\
\hline \multicolumn{6}{|c|}{$\chi^{2}=1,152.259, p=0.0000$} & \multicolumn{5}{|c|}{$\chi^{2}=1,152.259, p=0.0000$} \\
\hline \multirow{2}{*}{$\stackrel{0}{\circ}$} & $D$ & 0.4509 & 0.0249 & 326.5693 & 0.0000 & $D$ & 0.3429 & 0.0811 & 17.8625 & 0.0000 \\
\hline & $D \times f_{1}(t)$ & -0.1080 & 0.0849 & 1.6194 & 0.2032 & $D \times f_{2}(t)$ & 0.1080 & 0.0849 & 1.6194 & 0.2032 \\
\hline \multirow{2}{*}{ 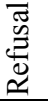 } & $D$ & -0.6208 & 0.0224 & 770.7904 & 0.0000 & $D$ & -0.3041 & 0.0670 & 20.6088 & 0.0000 \\
\hline & $D \times f_{1}(t)$ & 0.3167 & 0.0706 & 20.1078 & 0.0000 & $D \times f_{2}(t)$ & -0.3167 & 0.0706 & 20.1078 & 0.0000 \\
\hline \multirow{2}{*}{$\begin{array}{l}\dot{\Phi} \\
\frac{\overrightarrow{0}}{0}\end{array}$} & $D$ & 0.1750 & 0.0573 & 9.3187 & 0.0023 & $D$ & 0.1038 & 0.1811 & 0.3284 & 0.5666 \\
\hline & $D \times f_{1}(t)$ & 0.0713 & 0.1899 & 0.1408 & 0.7075 & $D \times f_{2}(t)$ & 0.0713 & 0.1899 & 0.1408 & 0.7075 \\
\hline \multicolumn{6}{|c|}{$\chi^{2}=99.73759, p=0.0000$} & \multicolumn{5}{|c|}{$\chi^{2}=99.73759, p=0.0000$} \\
\hline \multirow{2}{*}{$\stackrel{0}{\circ}$} & $Z$ & -0.0478 & 0.0245 & 3.8106 & 0.0509 & $Z$ & -0.4807 & 0.0754 & 40.5946 & 0.0000 \\
\hline & $Z \times f_{1}(t)$ & -0.4329 & 0.0793 & 29.7849 & 0.0000 & $Z \times f_{2}$ & 0.4329 & 0.0793 & 29.7849 & 0.0000 \\
\hline \multirow{2}{*}{ 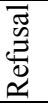 } & $Z$ & 0.0 & 0.0265 & 6.2240 & 0.0 & $Z$ & 0.1107 & 0.0815 & 1.8431 & 0.1746 \\
\hline & $Z \times f_{1}(t)$ & 7 & 0.0857 & 0.2713 & 0.6025 & $Z \times f_{2}(t)$ & -0.0 & 0.0857 & 0.2713 & 0.6025 \\
\hline \multirow{2}{*}{ 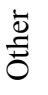 } & $Z$ & -0.3997 & 0.0557 & 51.5553 & 0.0000 & $Z$ & -0.1793 & 0.1900 & 0.8904 & 0.3454 \\
\hline & $Z \times f_{1}(t)$ & 0.2204 & 0.1980 & 1.2393 & 0.2656 & $Z \times f_{2}(t)$ & -0.2204 & 0.1980 & 1.2393 & 0.2656 \\
\hline
\end{tabular}

Source: own elaboration. 
Table 3. The results of estimation of the modified Lunn-McNeil model for the explanatory variable education

\begin{tabular}{|c|c|c|c|c|c|c|c|c|c|c|}
\hline $\begin{array}{l}\overrightarrow{0} \\
\stackrel{\vec{D}}{د} \\
\end{array}$ & $\begin{array}{l}\frac{0}{0} \\
. \frac{\pi}{\tilde{J}} \\
>\end{array}$ & 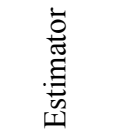 & 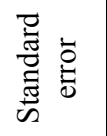 & 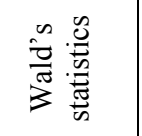 & $\begin{array}{l}\stackrel{0}{\Xi} \\
\frac{\pi}{\pi} \\
1 \\
2\end{array}$ & $\begin{array}{l}\frac{0}{0} \\
\frac{\pi}{\pi} \\
\frac{\pi}{\pi} \\
>\end{array}$ & 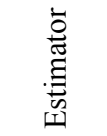 & 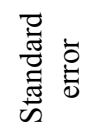 & 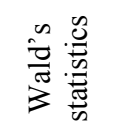 & $\begin{array}{c}0 \\
\frac{3}{\pi} \\
\frac{\pi}{1} \\
\vdots \\
2\end{array}$ \\
\hline & \multicolumn{5}{|c|}{ Model for the $f_{1}$ function } & \multicolumn{5}{|c|}{ Model for the $f_{2}$ function } \\
\hline \multicolumn{6}{|c|}{$\chi^{2}=1,646.327, p=0.0000$} & \multicolumn{5}{|c|}{$\chi^{2}=1,646.327, p=0.0000$} \\
\hline \multirow{10}{*}{$\stackrel{?}{\circ}$} & $S_{1}$ & -0.4851 & 0.0246 & 388.0049 & 0.0000 & $S_{1}$ & -0.4783 & 0.0756 & 40.0375 & 0.0000 \\
\hline & $S_{2}$ & -0.1066 & 0.0215 & 24.5178 & 0.0000 & $S_{2}$ & -0.1742 & 0.0690 & 6.3639 & 0.0117 \\
\hline & $S_{3}$ & 0.0535 & 0.0257 & 4.3364 & 0.0373 & $S_{3}$ & 0.0523 & 0.0875 & 0.3576 & 0.5499 \\
\hline & $S_{4}$ & 0.0802 & 0.0216 & 13.7858 & 0.0002 & $S_{4}$ & 0.0932 & 0.0686 & 1.8453 & 0.1743 \\
\hline & $S_{5}$ & 0.4579 & 0.0183 & 627.0162 & 0.0000 & $S_{5}$ & 0.5070 & 0.0620 & 66.8184 & 0.0000 \\
\hline & $S_{1} \times f_{1}(t)$ & 0.0067 & 0.0795 & 0.0072 & 0.9325 & $S_{1} \times f_{2}(t)$ & -0.0067 & 0.0795 & 0.0072 & 0.9325 \\
\hline & $S_{2} \times f_{1}(t)$ & -0.0675 & 0.0723 & 0.8719 & 0.3504 & $S_{2} \times f_{2}(t)$ & 0.0675 & 0.0723 & 0.8719 & 0.3504 \\
\hline & $S_{3} \times f_{1}(t)$ & -0.0012 & 0.0912 & 0.0002 & 0.9895 & $S_{3} \times f_{2}(t)$ & 0.0012 & 0.0912 & 0.0002 & 0.9895 \\
\hline & $S_{4} \times f_{1}(t)$ & .0129 & 0.0719 & 0.0323 & 0.8573 & $S_{4} \times f_{2}(t)$ & -0.0129 & 0.0719 & 0.0323 & 0.8573 \\
\hline & $S_{5} \times f_{1}(t)$ & 0.0491 & 0.0647 & 0.5758 & 0.4480 & $S_{5} \times f_{2}(t)$ & -0.0491 & 0.0647 & 0.5758 & 0.4480 \\
\hline \multirow{10}{*}{ 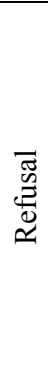 } & $S_{1}$ & 0.3401 & 0.0193 & 310.9918 & 0.0000 & $S_{1}$ & 0.3392 & 0.0556 & 37.1899 & 0.0000 \\
\hline & $S_{2}$ & 0.0955 & 0.0211 & 20.5344 & 0.0000 & $S_{2}$ & 0.0783 & 0.0614 & 1.6249 & 0.2024 \\
\hline & $S_{3}$ & 0.1459 & 0.0261 & 31.3103 & 0.0000 & $S_{3}$ & 0.1327 & 319 & 2.6242 & 0.1053 \\
\hline & $S_{4}$ & -0.1572 & 0.0248 & 40.0191 & 0.0000 & $S_{4}$ & & & 2.4287 & 0.1191 \\
\hline & $S_{5}$ & -0.4244 & 0.0264 & 257.5603 & 0.0000 & $S_{5}$ & -0.4383 & 0.0855 & 26.3089 & 0.0000 \\
\hline & $S_{1} \times f_{1}(t)$ & -0.0009 & 0.0589 & 0.0002 & 0.9877 & $S_{1} \times f_{2}(t)$ & 0.0009 & 0.0589 & 0.0002 & 0.9877 \\
\hline & $S_{2} \times f_{1}(t)$ & -0.0172 & 0.0649 & 0.0702 & 0.7910 & $S_{2} \times f_{2}(t)$ & 0.0172 & 0.0649 & 0.0702 & 0.7910 \\
\hline & $S_{3} \times f_{1}(t)$ & -0.0133 & 0.0860 & 0.0238 & 0.8775 & $S_{3} \times f_{2}(t)$ & 0.0133 & 0.0860 & 0.0238 & 0.8775 \\
\hline & $S_{4} \times f_{1}(t)$ & 0.0453 & 0.0759 & 0.3567 & 0.5503 & $S_{4} \times f_{2}(t)$ & -0.0453 & 0.0759 & 0.3567 & 0.5503 \\
\hline & $S_{5} \times f_{1}(t)$ & -0.0140 & 0.0895 & 0.0244 & 0.8758 & $S_{5} \times f_{2}(t)$ & 0.0140 & 0.0895 & 0.0244 & 0.8758 \\
\hline \multirow{10}{*}{$\begin{array}{l}\dot{\overline{0}} \\
\overrightarrow{\overline{0}}\end{array}$} & $S_{1}$ & -0.2383 & 0.0534 & 19.9345 & 0.0000 & $S_{1}$ & -0.1268 & 0.1565 & 0.6564 & 0.4179 \\
\hline & $S_{2}$ & -0.0835 & 0.0509 & 2.6880 & 0.1011 & $S_{2}$ & 0.1377 & 0.1460 & 0.8890 & 0.3458 \\
\hline & $S_{3}$ & 0.0270 & 0.0625 & 0.1873 & 0.6652 & $S_{3}$ & 0.1520 & 0.1974 & 0.5930 & 0.4413 \\
\hline & $S_{4}$ & 0.2203 & 0.0491 & 20.1074 & 0.0000 & $S_{4}$ & -0.0381 & 0.1696 & 0.0504 & 0.8223 \\
\hline & $S_{5}$ & 0.0745 & 0.0501 & 2.2160 & 0.1366 & $S_{5}$ & -0.1248 & 0.1829 & 0.4653 & 0.4951 \\
\hline & $S_{1} \times f_{1}(t)$ & 0.1115 & 0.1654 & 0.4549 & 0.5000 & $S_{1} \times f_{2}(t)$ & -0.1115 & 0.1654 & 0.4549 & 0.5000 \\
\hline & $S_{2} \times f_{1}(t)$ & 0.2212 & 0.1546 & 2.0458 & 0.1526 & $S_{2} \times f_{2}(t)$ & -0.2212 & 0.1546 & 2.0457 & 0.1526 \\
\hline & $S_{3} \times f_{1}(t)$ & 0.1249 & 0.2070 & 0.3642 & 0.5462 & $S_{3} \times f_{2}(t)$ & -0.1249 & 0.2070 & 0.3642 & 0.5462 \\
\hline & $S_{4} \times f_{1}(t)$ & -0.2584 & 0.1766 & 2.1401 & 0.1435 & $S_{4} \times f_{2}(t)$ & 0.2584 & 0.1766 & 2.1400 & 0.1435 \\
\hline & $S_{5} \times f_{1}(t)$ & -0.1993 & 0.1896 & 1.1047 & 0.2933 & $S_{5} \times f_{2}(t)$ & 0.1993 & 0.1896 & 1.1046 & 0.2933 \\
\hline
\end{tabular}

Source: own elaboration.

These tables are divided into two parts because of the application of function $f_{1}$ (left hand-side part of the tables) and $f_{2}$ (right-hand side parts of the tables). Not all parameters were statistically significant (at the significance level $\alpha=0.05$ ). Because of the two methods of variables coding, interpretation of this fact is different. In the case of the variables: gender, seniority and the number of registrations (Table 1) the lack of significance of parameter $\alpha_{k j}$ means that the intensity of de-registration of the 
The modified Lunn-McNeil model in the assessment of intensity of exiting...

Table 4. The results of estimation of the modified Lunn-McNeil model for the explanatory variable age

\begin{tabular}{|c|c|c|c|c|c|c|c|c|c|c|}
\hline 离 & $\begin{array}{l}\frac{0}{0} \\
\frac{\pi}{3} \\
\stackrel{\pi}{\frac{\pi}{0}}\end{array}$ & 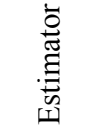 & 莺 & 告 & 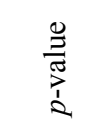 & 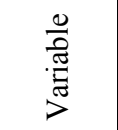 & 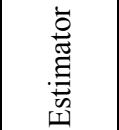 & 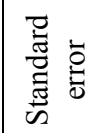 & 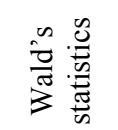 & $\begin{array}{l}\frac{0}{3} \\
\frac{\pi}{\pi} \\
1 \\
2\end{array}$ \\
\hline & \multicolumn{5}{|c|}{ Model for the $f_{1}$ function } & \multicolumn{5}{|c|}{ Model for the $f_{2}$ function } \\
\hline & \multicolumn{5}{|c|}{$\chi^{2}=2,302.876, p=0.0000$} & \multicolumn{5}{|c|}{$\chi^{2}=2,302.876, p=0.0000$} \\
\hline & $W_{1}$ & 0.2085 & 0.0281 & 55.0362 & 0.0000 & $W_{1}$ & 0.3515 & 0.1027 & 11.7173 & 0.0006 \\
\hline & $W_{2}$ & 0.3957 & 0.0209 & 358.5359 & 0.0000 & $W_{2}$ & 0.2537 & 0.0652 & 15.1180 & 0.0001 \\
\hline & $W_{3}$ & 0.1082 & 0.0251 & 18.5611 & 0.0000 & $W_{3}$ & -0.0491 & 0.0738 & 0.4437 & 0.5053 \\
\hline & $W_{4}$ & 0.1797 & 0.0266 & 45.7019 & 0.0000 & $W_{4}$ & 0.0116 & 0.0776 & 0.0223 & 0.8813 \\
\hline & $W_{5}$ & -0.1055 & 0.0333 & 10.0587 & 0.0015 & $W_{5}$ & -0.0328 & 0.0848 & 0.1494 & 0.6991 \\
\hline 0 & $W_{6}$ & 7865 & 0.0601 & 171.1917 & 0.0000 & $W_{6}$ & -0.5349 & 0.1246 & 18.4262 & 0.0000 \\
\hline$\stackrel{\circ}{\circ}$ & $W_{1} \times f_{1}(t)$ & 1430 & 0.1065 & 1.8049 & 0.1791 & $W_{1} \times f_{2}(t)$ & -0.1430 & 0.1065 & 1.8049 & 0.1791 \\
\hline & $W_{2} \times f_{1}(t)$ & 1420 & 0.0685 & 4.2949 & 0.0382 & $W_{2} \times f_{2}(t)$ & 0.1420 & 0.0685 & 4.2951 & 0.0382 \\
\hline & $W_{3} \times f_{1}(t)$ & -0.1573 & 0.0779 & 4.0756 & 0.0435 & $W_{3} \times f_{2}(t)$ & 0.1573 & 0.0779 & 4.0758 & 0.0435 \\
\hline & $W_{4} \times f_{1}(t)$ & 681 & 0.0820 & 4.2007 & 0.0404 & $W_{4} \times f_{2}(t)$ & 0.1681 & 0.0820 & 008 & 0.0404 \\
\hline & $W_{5} \times f_{1}(t)$ & 0.0727 & 0.0911 & 0.6370 & 0.4248 & $W_{5} \times f_{2}(t)$ & -0.0727 & 0.0911 & 0.6370 & 0.4248 \\
\hline & $W_{6} \times f_{1}(t)$ & 2516 & 0.1383 & 3.3084 & 0.0689 & $W_{6} \times f_{2}(t)$ & -0.2516 & 0.1383 & 3.3086 & 0.0689 \\
\hline \multirow{12}{*}{ 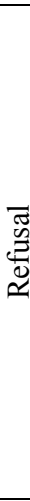 } & $W_{1}$ & 0.8539 & 0.0249 & 172.3950 & 0.0000 & $W_{1}$ & 0.5666 & 0.0881 & 41.3148 & 0.0000 \\
\hline & $W_{2}$ & 2878 & 0.0 & 15 & & $W_{2}$ & .2031 & 0.0623 & 10.6492 & \\
\hline & $W_{3}$ & 0.1507 & 0.0265 & 32.4168 & 0.0000 & $\overline{W_{3}}$ & -0.0999 & 0.0705 & 2.0078 & 0.1565 \\
\hline & $W_{4}$ & 0760 & 0.0 & & 0.0137 & $W_{4}$ & 25 & 83 & 7.9439 & 0.0048 \\
\hline & $W_{5}$ & -0.3760 & 0.0392 & 91.8362 & 0.0000 & $\overline{W_{5}}$ & 47 & 0.0846 & .2904 & 0.0215 \\
\hline & $W_{6}$ & 04 & 0.0 & 16 & & $W_{6}$ & 77 & 239 & 365 & 0. \\
\hline & $W_{1} \times f_{1}(t)$ & -0.2874 & 0.0916 & 9.8389 & 0.0017 & $W_{1} \times f_{2}(t)$ & 0.2874 & 0.0916 & 9.8389 & 0.0017 \\
\hline & $W_{2} \times f_{1}(t)$ & -0.0847 & 0.0664 & 1.6282 & 0.2020 & $W_{2} \times f_{2}(t)$ & 0.0847 & 0.0664 & 1.6282 & 0.2020 \\
\hline & $W_{3} \times f_{1}(t)$ & -0.2506 & 0.0753 & 11.0768 & 0.0009 & $W_{3} \times f_{2}(t)$ & 0.2506 & 0.0753 & \begin{tabular}{|l|}
11.0768 \\
\end{tabular} & 0.0009 \\
\hline & $W_{4} \times f_{1}(t)$ & 0.2685 & 0.0749 & 12.8375 & 0.0003 & $W_{4} \times f_{2}(t)$ & -0.2685 & 0.0749 & \begin{tabular}{|l|}
12.8375 \\
\end{tabular} & 0.0003 \\
\hline & $W_{5} \times f_{1}(t)$ & 1813 & 0.0933 & 3.7778 & 0.0519 & $W_{5} \times f_{2}(t)$ & \begin{tabular}{|l|}
-0.1813 \\
\end{tabular} & 0.0933 & 3.7778 & 0.0519 \\
\hline & $W_{6} \times f_{1}(t)$ & 0.1728 & 0.1397 & .5298 & 0.2162 & $W_{6} \times f_{2}(t)$ & -0.1728 & 0.1397 & 1.5298 & 0.2162 \\
\hline \multirow{12}{*}{$\begin{array}{l}\dot{\bar{\Xi}} \\
\stackrel{\Xi}{0}\end{array}$} & $W_{1}$ & -0.0426 & 0.0641 & 0.4418 & 0.5063 & $W_{1}$ & -0.2887 & 0.3244 & 0.7920 & 0.3735 \\
\hline & $W_{2}$ & -0.4551 & 0.0531 & 73.3209 & 0.0000 & $W_{2}$ & -0.4485 & 0.2004 & 5.0084 & 0.0252 \\
\hline & $W_{3}$ & -0.5862 & 0.0650 & 81.3709 & 0.0000 & $W_{3}$ & -0.1331 & 0.1835 & 0.5264 & 0.4681 \\
\hline & $W_{4}$ & -0.2625 & 0.0627 & 17.5001 & 0.0000 & $W_{4}$ & -0.6985 & 0.2473 & 7.9800 & 0.0047 \\
\hline & $W_{5}$ & 0.5631 & 0.0517 & 118.7425 & 0.0000 & $W_{5}$ & 0.3695 & 0.1772 & 4.3481 & 0.0371 \\
\hline & $W_{6}$ & 0.7833 & 0.0613 & 163.3568 & 0.0000 & $W_{6}$ & 1.1992 & 0.1551 & \begin{tabular}{|l|}
59.7521 \\
\end{tabular} & 0.0000 \\
\hline & $W_{1} \times f_{1}(t)$ & -0.2461 & 0.3307 & 0.5540 & 0.4567 & $W_{1} \times f_{2}(t)$ & 0.2461 & 0.3307 & 0.5540 & 0.4567 \\
\hline & $W_{2} \times f_{1}(t)$ & 0.0066 & 0.2073 & 0.0010 & 0.9745 & $W_{2} \times f_{2}(t)$ & -0.0066 & 0.2073 & 0.0010 & 0.9745 \\
\hline & $W_{3} \times f_{1}(t)$ & 0.4531 & 0.1947 & 5.4182 & 0.0199 & $W_{3} \times f_{2}(t)$ & -0.4531 & 0.1947 & 5.4182 & 0.0199 \\
\hline & $W_{4} \times f_{1}(t)$ & -0.4360 & 0.2551 & 2.9211 & 0.0874 & $W_{4} \times f_{2}(t)$ & 0.4360 & 0.2551 & 2.9211 & 0.0874 \\
\hline & $W_{5} \times f_{1}(t)$ & -0.1936 & 0.1846 & 1.1000 & 0.2943 & $W_{5} \times f_{2}(t)$ & 0.1936 & 0.1846 & 1.1000 & 0.2943 \\
\hline & $W_{6} \times f_{1}(t)$ & 0.4159 & 0.1668 & 6.2174 & 0.0127 & $W_{6} \times f_{2}(t)$ & -0.4159 & 0.1668 & 6.2174 & 0.0127 \\
\hline
\end{tabular}

Source: own elaboration. 
analysed group is not statistically different from the intensity of de-registrations of the reference group. For the variables education and age (Tables 3 and 4) it means that the intensity of de-registration of the given group is not statistically different from the mean intensity of de-registration for all groups. On the contrary, the lack of significance of parameter $\delta_{k j}$ indicates that the change of intensity of de-registration due to the $k$-th cause for the $j$-th attribute in the transition into the state of long-term unemployment is not statistically significant.

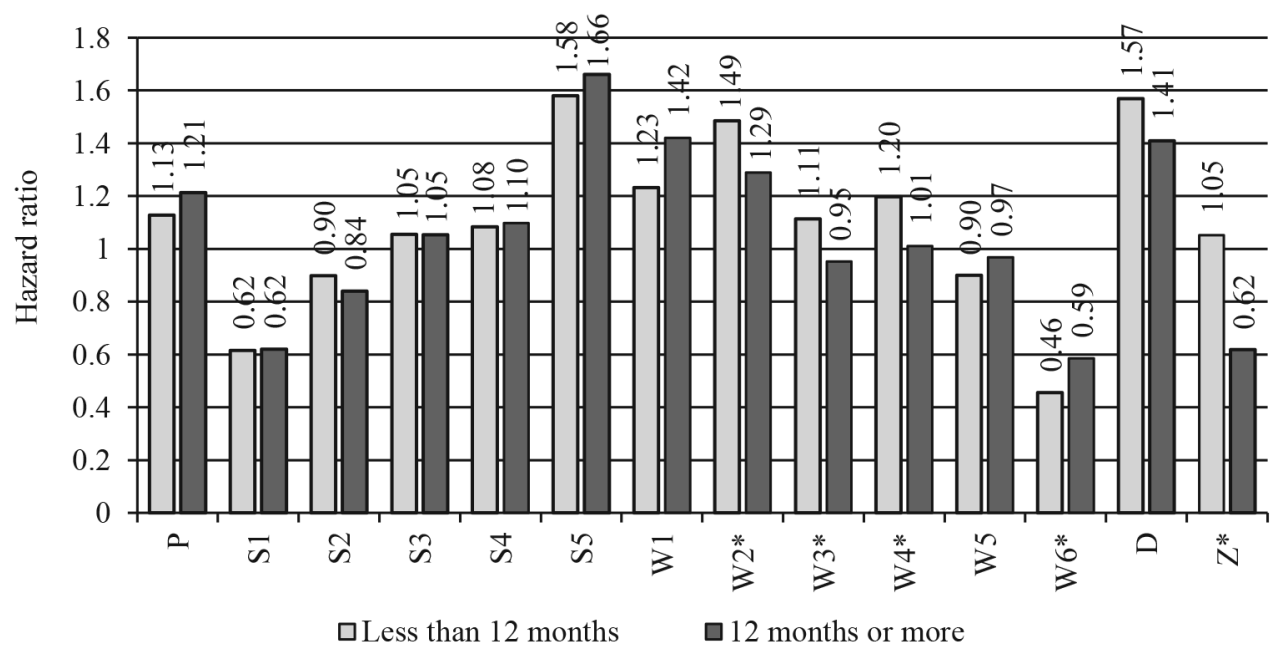

Fig. 1. Relative intensity of taking up a job

Source: own elaboration.

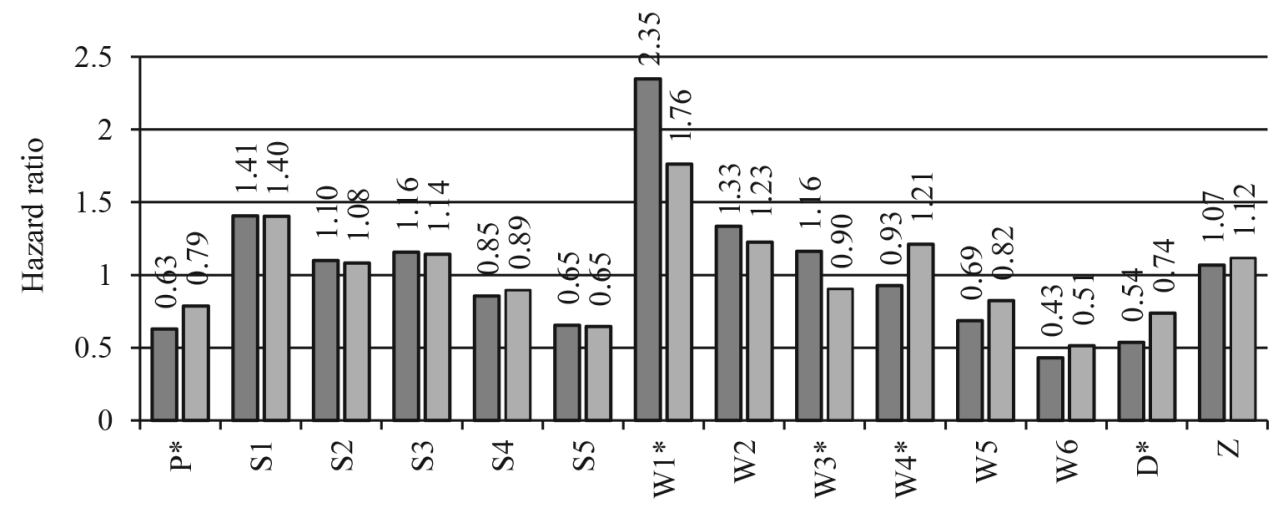

- Less than 12 months $\quad \square 12$ months or more

Fig. 2. Relative intensity of refusal

Source: own elaboration. 
Figures 1 to 3 present the relative intensity (hazard ratios HR) before and after the state of long-term unemployment. The significance of parameters akj was marked by a thick border, and for parameters $\delta_{k j}$ by a star.

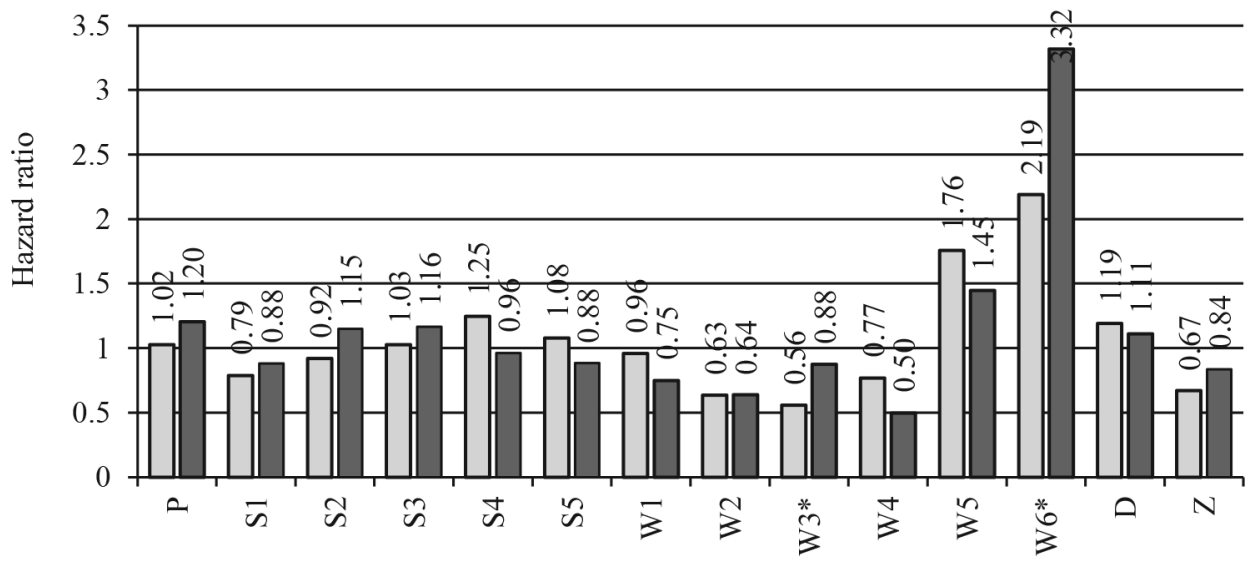

पLess than 12 months $\quad \square 12$ months or more

Fig. 3. Relative intensity of de-registration due to other causes

Source: own elaboration.

From the point of view of the labour market policy, the identification of persons with problems in finding a job and persons that withdraw from the cooperation with the labour office due to unknown causes is important. Before the twelfth month since the moment of registration, persons least likely to took up a job were males with short seniority, registered for the first time, with the lowest education and 60-64 years old. The same groups of persons were removed most intensively because of the refusal (with the exception of persons aged 18-24). Similar results were obtained after the transition into the state of long-term unemployment. The only difference was observed for persons registered subsequently, who took a job least intensively. The attributes of the unemployed persons matter to a lesser degree than in the case of work and refusal differentiated the intensity of de-registration for other causes (statistically insignificant parameters prevailed). Before the twelfth month this was done most intensively by persons with a seniority of 1 year and more, registered for the first time, with secondary vocational education and 60-64 years old. In the group of the long-term unemployed they were the oldest ones. In the case of de-registration due to other causes, persons of 55-59 and 60-64 deserve attention. They were leaving the register most intensively both before and after the state of long-term unemployment. Data analysis indicated that they were mostly those who are mainly accepting a pension, pre-retirement allowance or retirement pension. As a result, 
we can say that these persons were not interested in finding a job, but rather "lasting" until the age at which they are entitled to certain benefits. The analysis of significance of parameter $\delta_{k j}$ leads to the conclusion that in the case of all forms of de-registration, the age of the unemployed person has the biggest impact on the intensity of exiting unemployment. Gender (refusal), seniority (refusal) and the number of subsequent registrations (job) influenced this intensity to a slightly less degree. On the contrary, education level had no impact on the intensity of exiting unemployment.

\section{Conclusions}

The analysis of unemployment may raise two issues: the identification of persons to whom help in seeking employment should be directed, and the assessment of the efficiency of the actions taken in order to prevent the unemployment. The research presented in the article focuses on the former with regard to the long-term unemployed . From the labour market policy point of view it is important to identify the group of persons that have problems in finding a job or, for unknown reasons, withdraw from the co-operation with the labour office. Therefore, in general conclusions, the article focused on persons that can be characterised by the lower intensity of taking up a job or the higher intensity of removal from the register due to unknown causes.

The modification or the combination of the Lunn-McNeil model with the model of non-proportional hazard allowed to assess the intensity of use of various forms of unemployment. The selection of function $f$ enabled to estimate the change of intensity after transition into the state of long-term unemployment. The hypothesis presented in the introduction was confirmed only partially. Not all attributes had a significant impact on the change of the relative hazard. Education did not have any impact at all. The analysis also showed the groups of persons with the least intensity of taking up a job. They were males with short seniority, registered for the first time and with the lowest education. However, before 12 months they were persons 60-64 years old, and after that those 18-24 years old. At the same time they were the persons, who most intensively withdrew from the co-operation with the labour office. These people should be taken into account when developing labour market policies.

\section{Bibliography}

Bieszk-Stolorz B., 2013, Analiza historii zdarzeń w badaniu bezrobocia, Volumina.pl Daniel Krzanowski, Szczecin.

Bieszk-Stolorz B., 2018, Ocena wpływu ptci na formę wyjścia z bezrobocia, Wiadomości Statystyczne, 6(685), pp. 23-38.

Brzeziński J., 2004, Metodologia badań psychologicznych, Wydawnictwo Naukowe PWN, Warszawa. 
Crowder M., 1994, Identifiability Crises in Competing Risks, International Statistical Review, 62(3), pp. 379-391, DOI: 10.2307/1403768.

Crowder M., 1996, On assessing independence of competing risks when failure times are discrete, Lifetime Data Analysis, 2(2), pp. 195-209, DOI: 10.1007/BF00128575.

Crowder M., 1997, A test for independence of competing risks with discrete failure times, Lifetime Data Analysis, 3(3), pp. 215-223, DOI: 10.1023/A:1009696830515.

Gooley T.A., Leisenring W., Crowley J., Storer B.E., 1999, Estimation of failure probabilities in the presence of competing risks: New representations of old estimators, Statistics in Medicine, 18(6), pp. 695-706, DOI: 10.1002/(SICI)1097-0258(19990330)18:6<695::AID-SIM60>3.0.CO;2-O.

Klein J.P., Bajorunaite R., 2004, Inference for Competing Risks, [in:] Balakrishnan N., Rao C.R. (eds.), Handbook of Statistics: Advances in Survival Analysis, Elsevier, New York, pp. 291-311.

Klein J.P., Moeschberger M.L., 1984, Asymptotic bias of the product limit estimator under dependent competing risks, Indian Journal of Productivity, Reliability and Quality Control, 9, pp. 1-7.

Klein J.P., Moeschberger M.L., 2003, Survival Analysis: Techniques for Censored and Truncated Data, Second Edition, Springer-Verlag, New York.

Kleinbaum D., Klein M., 2012, Survival Analysis. A Self-Learning Text, Third Edition, SpringerVerlag, New York.

Landmesser J.M., 2008, Modele ryzyka konkurencyjnego dla czasu trwania czynności, [in:] Trzaskalik T. (ed.), Modelowanie Preferencji a Ryzyko '08, pp. 371-385, Wydawnictwo Akademii Ekonomicznej im. Karola Adamieckiego w Katowicach, Katowice.

Pepe M.S., 1991, Inference for events with dependent risks in multiple endpoint studies, Journal of the American Statistical Association, 86(415), pp. 770-778, DOI: 10.1080/01621459.1991. 10475108.

Walesiak M., 1996, Metody analizy danych marketingowych, PWN, Warszawa.

\section{ZMODYFIKOWANY MODEL LUNNA-MCNEILA W OCENIE INTENSYWNOŚCI WYJŚCIA Z BEZROBOCIA}

Streszczenie: Celem artykułu jest ocena intensywności względnej wychodzenia z bezrobocia osób długotrwale bezrobotnych w zależności od ich cech: płci, wieku, wykształcenia, stażu pracy i liczby kolejnych zarejestrowań. W badaniu wykorzystano zmodyfikowany model Lunna-McNeila dla różnych rodzajów zdarzeń konkurujących: podjęcie pracy, wykreślenie i pozostałe przyczyny wyrejestrowania. Modyfikacja polegała na wykorzystaniu warstwowego modelu nieproporcjonalnych hazardów Coxa, który pozwolił na ocenę hazardu względnego po przejściu w stan długotrwałego bezrobocia. W badaniu wykorzystano dane osób zarejestrowanych w Powiatowym Urzędzie Pracy w Szczecinie. Największy wpływ na zmianę hazardu względnego w sytuacji przejścia w stan długotrwałego bezrobocia miał wiek, natomiast istotnego wpływu nie miał poziom wykształcenia. Badanie umożliwiło wskazanie grup osób najmniej intensywnie podejmujących pracę i najintensywniej odmawiających podjęcia zatrudnienia. Na te osoby należy zwrócić uwagę w trakcie kreowania polityki rynku pracy.

Słowa kluczowe: model Lunna-McNeila, model nieproporcjonalnego hazardu, zdarzenia konkurujące, długotrwałe bezrobocie. 